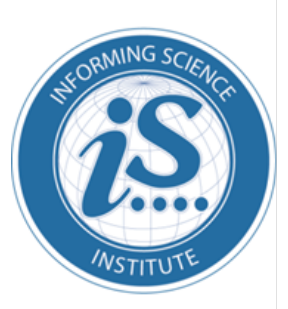

Proceedings of the Informing Science + Information Technology Education Conference

An Official Publication

of the Informing Science Institute

InformingScience.org

InformingScience.org/Publications

June 30 - July 4, 2019, Jerusalem, Israel

\title{
A Project Management Perspective of PhD SUPERVISION PROCESS - TOWARDS EFFECTIVE AND EFFICIENT MODEL [ABSTRACT]
}

$\begin{array}{ll}\text { Gali Naveh* } & \begin{array}{l}\text { Shamoon College of Engineering, GaliNaveh@sce.ac.il } \\ \text { Beer- Sheva, Israel }\end{array} \\ \text { Dorit Tubin } & \begin{array}{l}\text { Ben-Gurion University of the Negev, dorittu@,bgu.ac.il } \\ \text { Beer- Sheva, Israel }\end{array} \\ * \text { Corresponding author } & \end{array}$

ABSTRACT

Aim/Purpose Continuing low percentage of on-time-completion of doctoral studies suggest the exploration of new approaches to the process is desirable.

Background $\quad \mathrm{PhD}$ studies may be viewed as a project- it is a temporary endeavor undertaken to create a unique product. Project management practices have proven to be helpful in numerous domains.

Methodology Process analysis method will be applied, using: 1) semi-structured interviews with supervisors and supervisee, 2) data gathered by the school of advance graduate studies in higher education institute.

Contribution The research will explore the appropriated measurable indicators of successful $\mathrm{PhD}$ and identify project management practices that promote better process and outcomes of PhD studies.

Impact on Society Better and more efficient process will support lower individual and national spending on doctoral studies

Future Research Further research should explore relevance of the findings in various settings (characteristics of the supervisor and supervisee, higher education system etc.)

Keywords doctoral studies, supervision, project management

\footnotetext{
Accepting Editor: Eli Cohen | Received: January 31, 2019 | Revised: February 17, 2019 |

Accepted: February 18, 2019.

Cite as: Naveh, G., \& Tubin, D. (2019). A project management perspective of PhD supervision process - Towards effective and efficient model [Abstract]. Proceedings of the Informing Science and Information Technology Education Conference, Jerusalem, Israel, pp. 95-97. Santa Rosa, CA: Informing Science Institute. https://doi.org/10.28945/4349
}

(CC BY-NC 4.0) This article is licensed to you under a Creative Commons Attribution-NonCommercial 4.0 International License. When you copy and redistribute this paper in full or in part, you need to provide proper attribution to it to ensure that others can later locate this work (and to ensure that others do not accuse you of plagiarism). You may (and we encourage you to) adapt, remix, transform, and build upon the material for any non-commercial purposes. This license does not permit you to use this material for commercial purposes. 


\section{EXTENDED ABSTRACT}

Traditionally, doctoral studies has been observed mainly as an apprenticeship process (Golde, Bueschel, Jones, \& Walker, 2006). Park (2005) citing others, depicts that PhD is a period of learning the tricks of the trade and the art and the science of research. However, the continuing low percentage of on-time-completion (Elgar, 2003; Kim \& Otts, 2010; National Research Council, 2011; Roberts, Tinari, \& Bandlow, 2019; Sowell, 2008), suggest the exploration of other approaches is desirable. Indeed, calls for a more structured and better coordinated process have been voiced and some efforts have been made (e.g., Golde et al., 2006; Roberts, Tinari, \& Bandlow, 2019; Sowell, 2008). Such structure may be offered by exploring $\mathrm{PhD}$ studies within the project management framework. As a project, $\mathrm{PhD}$ studies is a temporary endeavor undertaken to create a unique product (A guide to the project management body of knowledge: PMBOK (®) guide, 2017), i.e., skilled researcher. Project management practices have proven to be helpful in numerous domains (engineering, software, development etc.). Thus, this research will explore the added value of project management best practices to the PhD supervision process. Specifically, this research aims to explore the following questions:

- What are the appropriated measurable indicators of successful $\mathrm{PhD}$ ?

In order to promote quality education of $\mathrm{PhD}$ students, success indicators are required. Measurable success indicator will facilitate effective control over the process and thus supports the promotion of quality and efficiency.

- What project management practices promote better outcomes of $\mathrm{PhD}$ studies?

Following successful PhD students, based on the success measurements defined, this research aimed at identifying project management practices contribution to the supervision process.

Two primary research methodologies will be used in this research. In order to analyze the supervision process and identify the fit between project management best practices and the supervision process practices, a process analysis method will be used (Poole, Van de Ven, Dooley, \& Holmes, 2000; Van de Ven \& Poole, 2005). This analysis will support the development of a model for a supervision process promoting successful $\mathrm{PhD}$. Two groups of subjects will be in the focus of this research. The first is supervisors of $\mathrm{PhD}$ students, from two faculties (social science and engineering) with varying degrees of experience in supervision. Such choice will provide a wide range of inputs relevant to the research. The second group of subjects will be the supervisors' former supervisee who completed their studies (i.e., PhD graduates). In semi-structured interviews, the subjects will be asked about the supervision process and its output (e.g., goals definition, measurable milestones, submission to conferences and journals, etc.). The second methodology to be used in this research, aimed at measuring successful results of the process will be the analysis of relevant data gathered by the school of advance graduate studies in the institute regarding academic performances and experience of the supervisors, and academic performances of the supervisee.

\section{REFERENCES}

A guide to the project management body of knowledge: PMBOK (®) guide. (2017). Project Management Institute: Newtown Square, PA, USA (6th ed.). Project Management Institute. https://doi.org/10.1109/ieeestd.2011.6086685

Elgar, F. J. (2003). PhD degree completion in Canadian universities. Nova Scotia, Canada: Dalhousie University, 1-31.

Golde, C., Bueschel, A., Jones, L., \& Walker, G. E. (2006). Apprenticeship and intellectual community: Lessons from the Carnegie Initiative on the Doctorate. In Conference proceedings of the National Conference on Doctoral Education and the Faculty of the Future. Cornell University, Ithaca, NY: The Carnegie Foundation for the Advancement of Teaching.

Kim, D., \& Otts, C. (2010). The effect of loans on time to doctorate degree: Differences by race/ethnicity, field of study, and institutional characteristics. The Journal of Higher Education, 81(1), 1-32.

https://doi.org/10.1080/00221546.2010.11778968 
National Research Council. (2011). Research-Doctorate Programs in the Biomedical Sciences: Selected Findings from the NRC Assessment. J. F. Lorden, C. V. Kuh, \& J. A.Voytuk (Eds.). Washington, DC: National Academies Press. https://doi.org/10.17226/13213

Park, C. (2005). New variant PhD: The changing nature of the doctorate in the UK. Journal of Higher Education Policy and Management, 27(2), 189-207. https://doi.org/10.1080/13600800500120068

Poole, M. S., Van de Ven, A. H., Dooley, K., \& Holmes, M. E. (2000). Organizational change and innovation processes: Theory and methods for research. Oxford University Press.

Roberts, L., Tinari, C. M., \& Bandlow, R. (2019). An effective doctoral student mentor wears many hats and asks many questions. International Journal of Doctoral Studies, 14, 133-159. https://doi.org/10.28945/4195

Sowell, R. (2008). PhD completion and attrition: Analysis of baseline data. Washington, DC: Council of Graduate Schools, 1-23.

Van de Ven, A. H., \& Poole, M. S. (2005). Alternative approaches for studying organizational change. Organization Studies, 26(9), 1377-1404. https://doi.org/10.1177/0170840605056907

\section{BIOGRAPHIES}

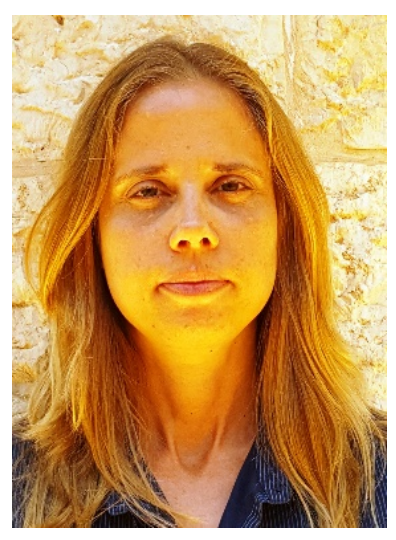

Gali Naveh is a Lecturer and the head of the Information System track in the department of Industrial Engineering and Management at Shamoon College of Engineering, Israel. Her main interest is institutional processes in higher education. She holds knowledge and business experience in project management and the analysis of working processes, and the design and implementation of their improvement.

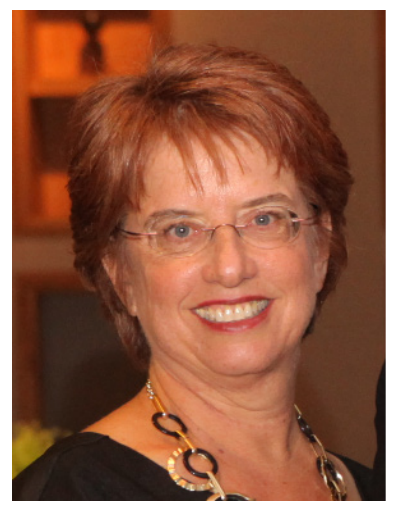

Dorit Tubin is associate professor in the Department of Education, and head of the Principal Training Program, at Ben Gurion University, Israel. Her main interest is professional training and preparation (principal, teacher), educational organizations, school leadership and effectiveness, Innovative learning environment and national culture and schooling 